\title{
Dry Calorimetry at the Savannah River Site
}

\section{Lee A. ReFalo}

Westinghouse Savannah River Company

Savannah River Site

Aiken, SC 29808

\author{
A paper for the INTERNATIONAL WORKSHOP ON CALORIMETRY \\ Joint Research Center \\ ISPRA-Italy \\ Perla Laboratory \\ March 23--27, 1992
}

\section{DISCLAIMER}

This report was prepared as an account of work sponsored by an agency of the United States Government. Neither the United States Government nor any agency thereof, nor any of their employees, makes any warranty, express or implied, or assumes any legal liability or responsibility for the accuracy, completeness, or usefulness of any information, apparatus, product, or process disclosed, or represents that its use would not infringe privately owned rights. Reference herein to any specific commercial product, process, or service by trade name, trademark, manufacturer, or otherwise does not necessarily constitute or imply its endorsement, recommendation, or favoring by the United States Government or any agency thereof. The views and opinions of authors expressed herein do not necescarily state or reflect those of the United States Government or any agency thereof.

\section{MASTER}

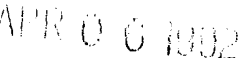

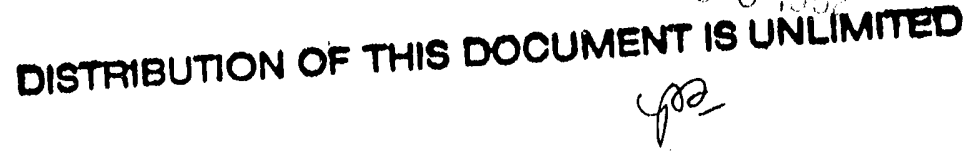

This paper was prepared in connection with work done under Contract No. DE-AC09-89SR18035 with the U.S. Department of Energy. By acceptance of this paper, the publisher and/or recipient acknowledges the U.S. Government's right to retain a nonexclusive, royalty-free license in and to any copyright covering this paper, along with the right to reproduce and to authorize others to reproduce all or part of the copyrighted paper. 


\section{Dry Calorimetry at the Savannah River Site}

\section{Introduction}

Heat flow calorimeters are used at the Savannah River Site to assay radioactive sources by measuring the emitted thermal power. The radioactive source is placed in a constant temperature environment and its thermal output is measured by non-destructive assay techniques. The isotopic mass is computed from the measured power through known watts/gram constants for each of the isotopes.

The Equipment Engineering Section of the Savannah River Laboratory has developed calorimetric techniques which provide major improvements over other calorimeters. Improvements are in the areas of greater precision, reduced maintenance, and thermal control without using water. The elimination of water reduces criticality concerns during assay of fissionable materials and reduces health concerns during assay of tritium.

\section{Two Dry Calorimeter Designs}

Equipment Engineering Section has developed two basic dry calorimeter designs. The designs are identical in concept; however, they differ to accommodate different power levels. Each design has been tested demonstrating proof of concept. the current designs are for low wattage samples, .1 to 10 watts, and high wattage samples, 40 to 140 watts.

\section{Functional Description}

The calorimeter is a precision heat control and measurement device. Temperature control through data acquisition and control systems ensure total heat accountability. The calorimeter consists of a thermal well, thermal shields, power supplies, data acquisition system, and a computer system for control.

The calorimeter operates by direct power replacement. Initially, the calorimeter is supplied with a baseline power which is removed via an accurately controlled and monitored heat removal path. The radioactive sample is inserted in the thermal well after the calorimeter has stabilized at the baseline power. The power required to maintain the heat removal system at the baseline power will be decreased by exactly the thermal output of the sample.

To achieve the power replacement measurement, an electrical heater is attached to the base of the thermal well. A small area, high thermal conductivity power metering rod is also attached to the base of the thermal well. The other end of the power metering rod is connected to a heat removal device such as a peltier heat pump. Two precise thermistors are placed on this power metering rod. The electrical heater supplies the power required to maintain the thermistor located on the hot end of the power metering rod at a fixed temperature. the heat pump removes power and holds the cold end thermistor at a fixed temperature. The constant temperature difference across the power metering ror establishes a fixed and constant heat flow. Thus, any power added by a sample in the thermal well is measured by the corresponding decrease in power to the heater.

A unique configuration of heat shields keep heat flow, other than through the power metering rod, to a very low and constant value. Heat shielding begins with a primary shield of thin, high conductivity material connected to the well at a point between the heat source and the rod but insulated over all other areas. Only a small amount of heat flows through the shield so temperature is very uniform throughout the shield. By precise temperature measurements, the temperature of a secondary, more massive shield, can be controlled to match very closely the temperature of the primary shield. This close match in temperature reduces heat flow into and out of the well to an extremely small and stable amount. To minimize thermal noise from room temperature variations, a third shield surrounds the secondary shield. This shield is held at a fixed, constant temperature. Precision and temperature control of the secondary shield is thereby improved.

\section{Baseline Repeatability and Measurement Precision}

The data collected for both calorimeters will be presented here and compared with current production calorimeters. All the data was collected in production facilities by analysts in the field. The facilities where these calorimeters are used have minimal thermal regulation. Charts A \& B show the improvement in baseline repeatability for the low wattage calorimeter. The data for charts A \& B were collected over the same three month time frame. Charts C \& D show the precision comparison of the low wattage calorimeters. The data on charts C \& D were compiled using a 0.1 watt radiometric standard and show the ratio of T/A.

The data in charts $\mathrm{E}, \mathrm{F}$, \& $\mathrm{G}$ below were collected from the high wattage calorimeters. charts $\mathrm{E} \& \mathrm{~F}$ show the baseline repeatability comparison between the 
production calorimeter and the new dry calorimeter. The new calorimeter replaced the production calorimeter and there is no radiometric standards information available for the production calorimeter. Chart $G$ shows the precision of the naw dry, high wattage calorimeter with data collected using a 140 watt radiometric standard. The reported precision of the production calorimeter was approximately $.25 \%, 1$ sigma. 

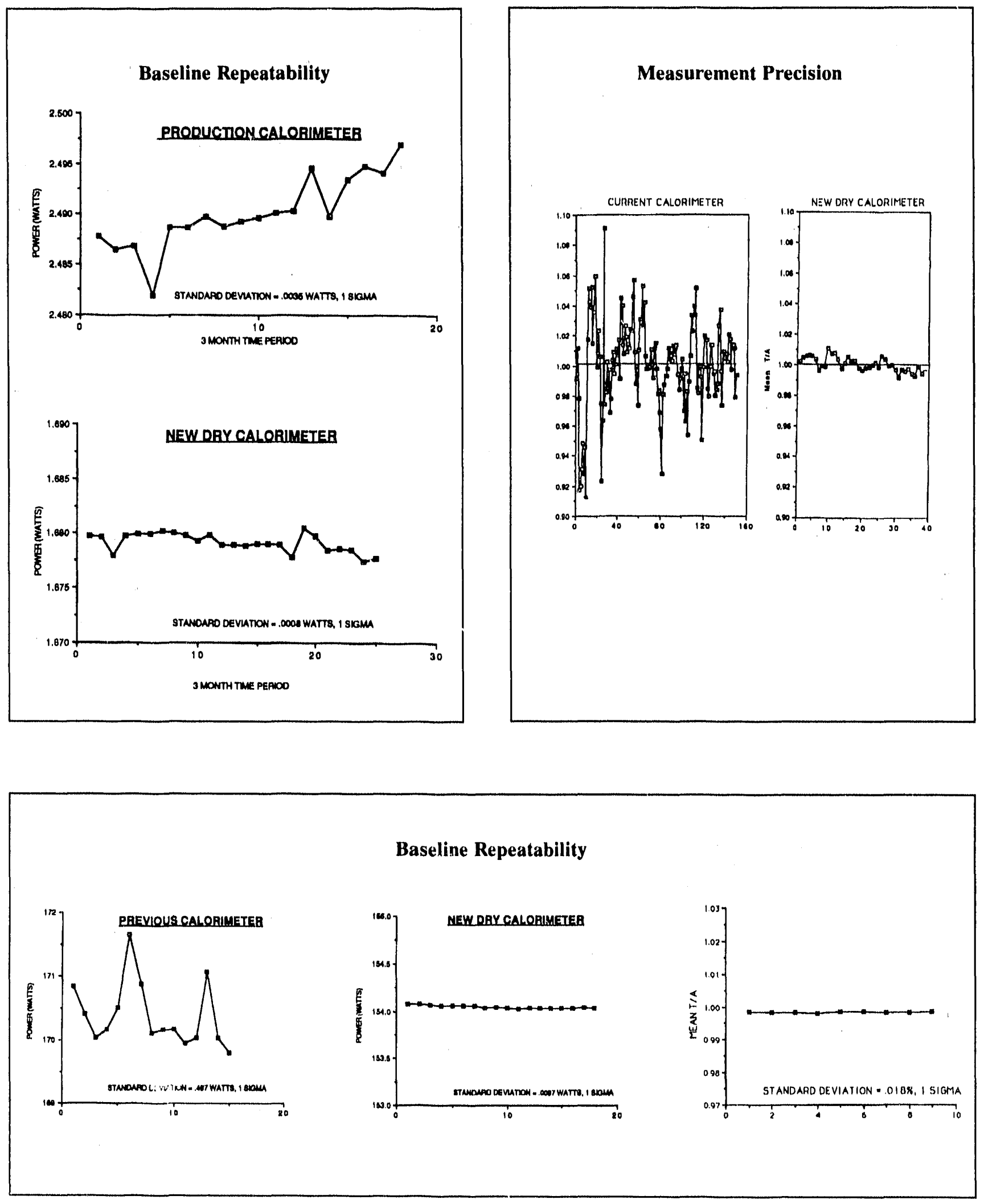

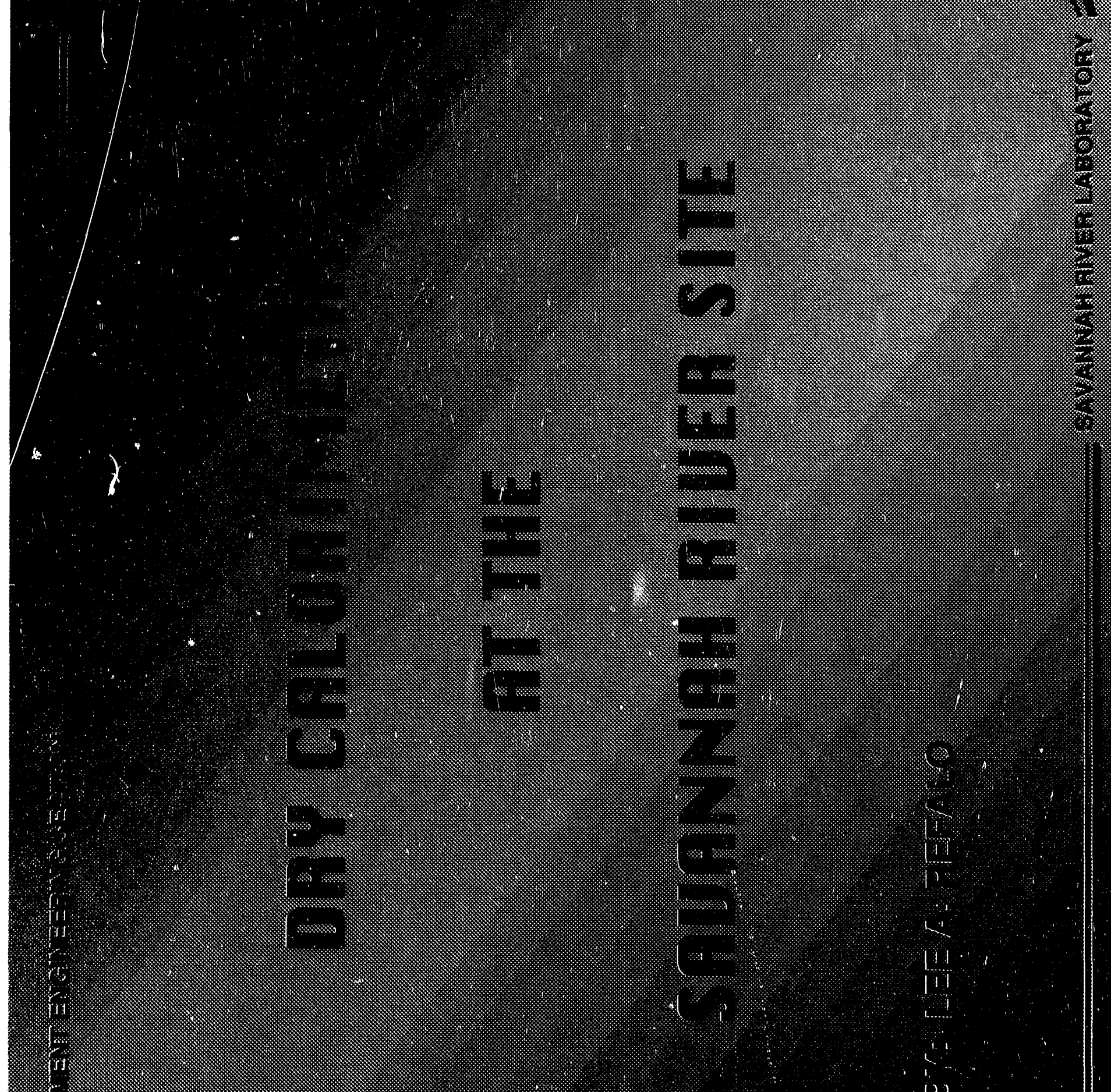

$\frac{1}{2}$
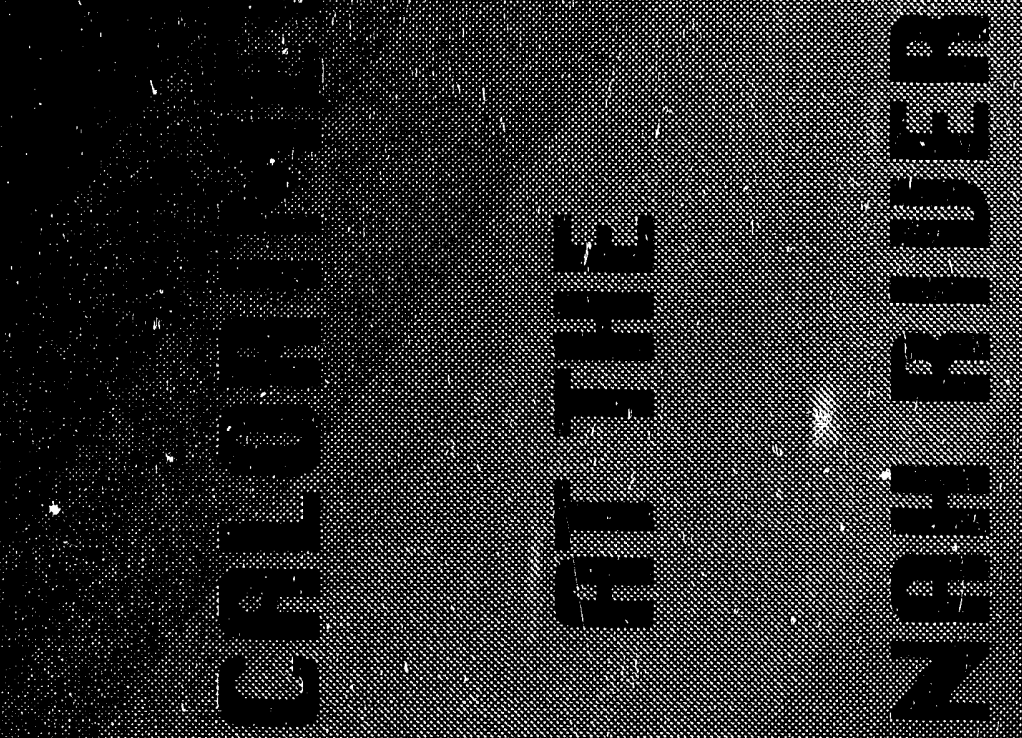
SLIDE \# 1 DISCUSSION

GOOD MORNING, I WILL BE TALKING ABOUT SOME DRY CALORIMETERS WE HAVE DEVELOPED AT THE SAVANNAH RIVER SITE. 


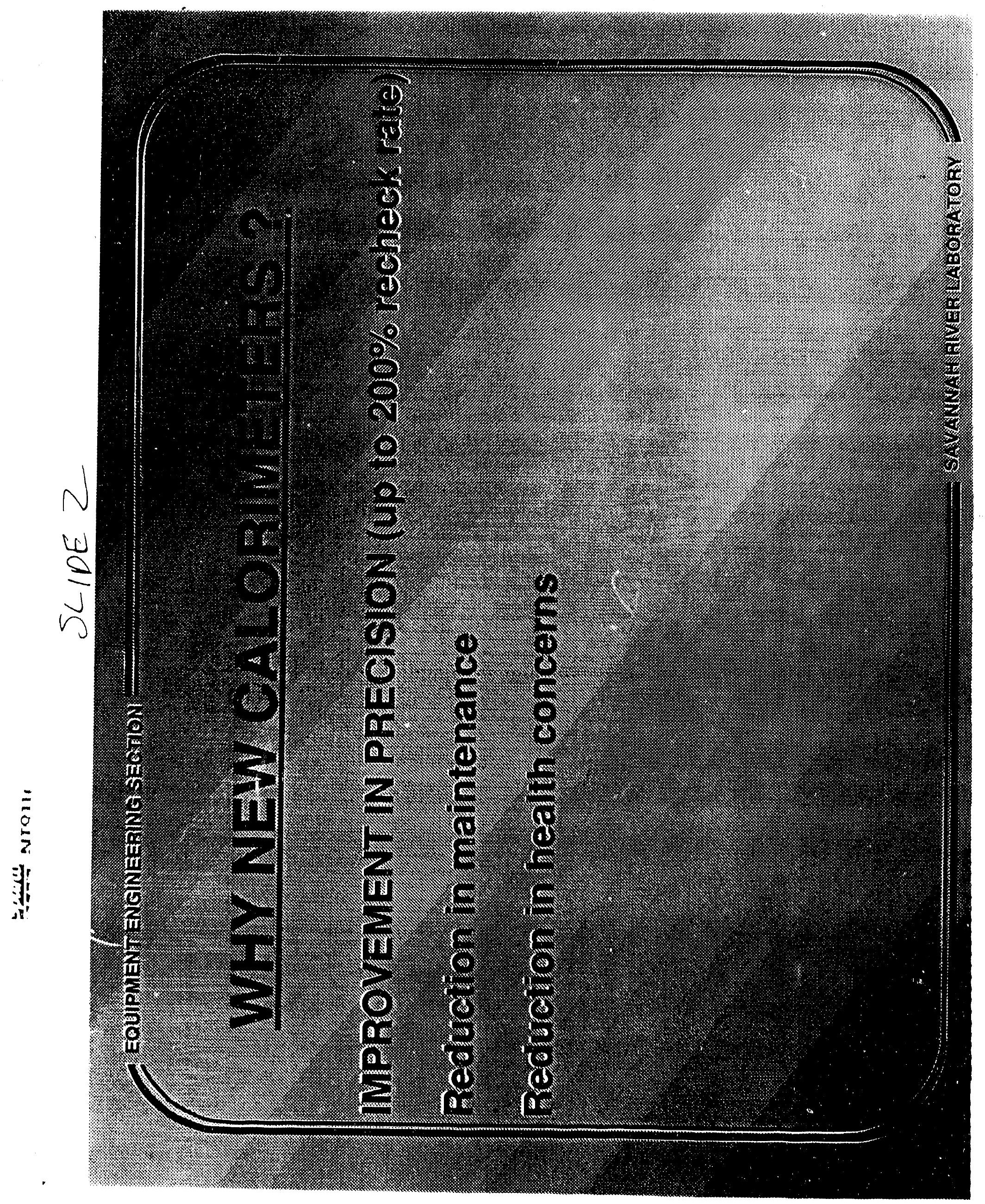


SLIDE \#2 DISCUSSION

WHY WOULD WE WANT TO DEVELOP NEW CALORIMETERS?

WE NEEDED AN IMPROVEMENT IN PRECISION, SPECIFICALLY FOR LOW WATTAGE SAMPLES WHERE WE HAD AS MUCH AS A $200 \%$ RECHECK RATE. ADDITIONALLY, WE WANTED TO REDUCE MAINTENANCE AND HEALTH CONCERNS. 


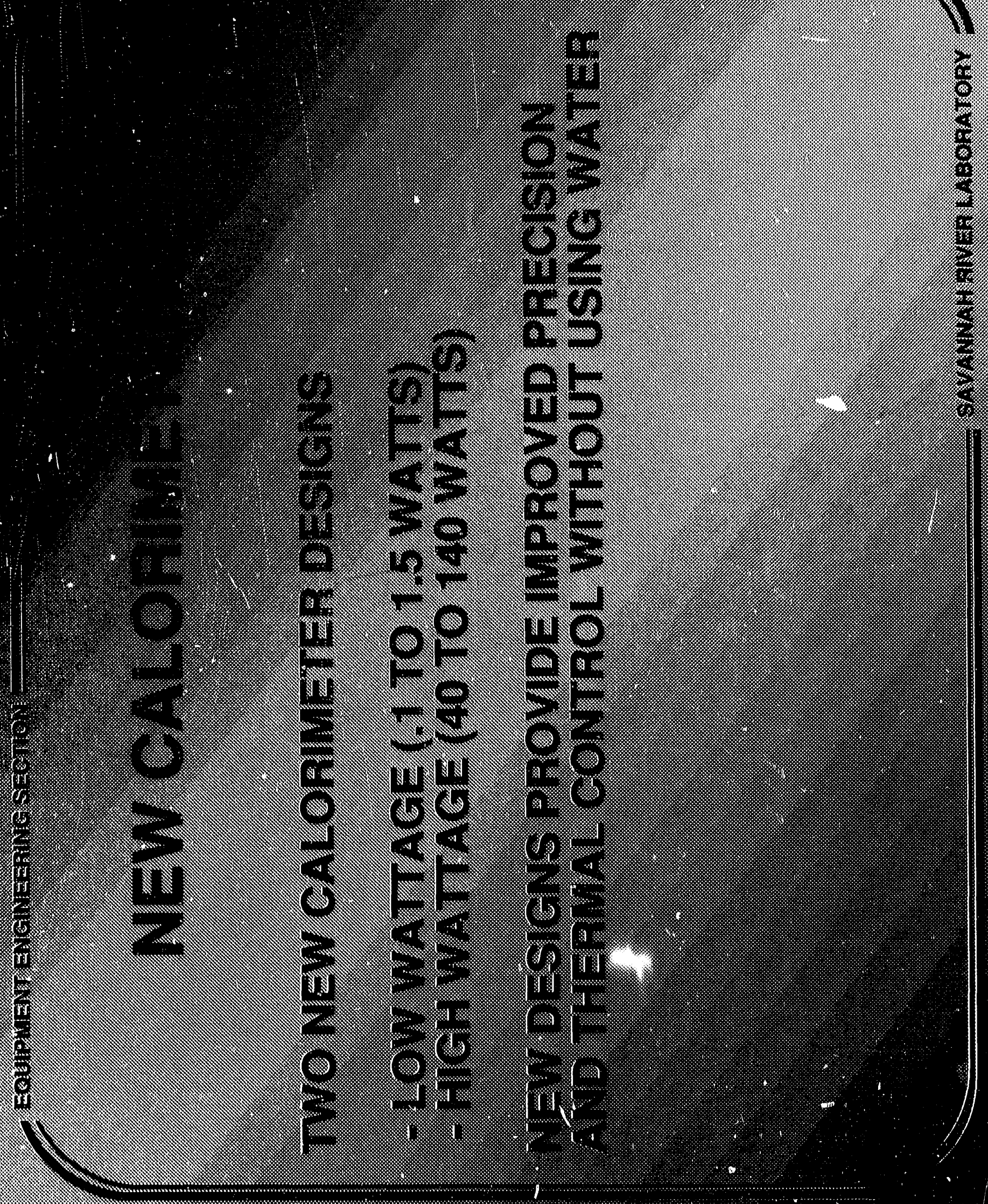


SLIDE \#3 DISCUSSION

WE HAVE DEVELOPED TWO NEW CALORIMETER DESIGNS AT THE SAVANNAH RIVER SITE.

ONE FOR LOW WATTAGE SAMPLES WHICH MEASURE SAMPLES FROM ABOUT .1 WATTS TO 1.5 WATTS

AND ONE HIGH WATTAGE CALORIMETER FOR SAMPLES FROM 40 TO ABOUT 140 WATTS.

BOTH OF THESE CALORIMETERS OFFER IMPROVED PRECISION AND THERMAL CONTROL WITHOUT USING WATER. 


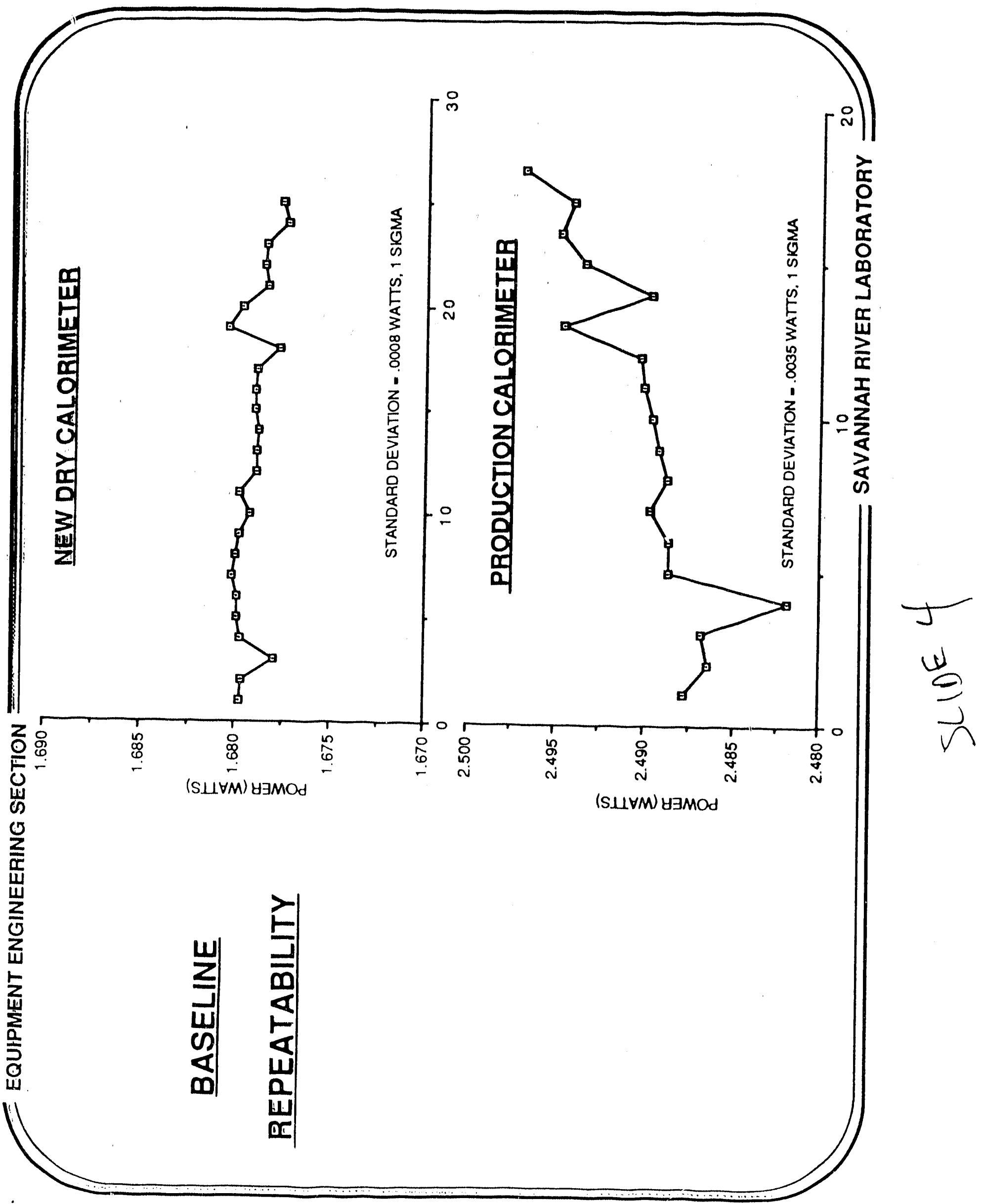


I WOULD LIKE TO SHOW YOU HOW WELL THESE CALORIMETERS PERFORM.

ALL OF THE DATA ON THE CHARTS I'LL BE SHOWING YOU WAS COLLECTED IN A PRODUCTION ENVIRONMENT BY ANALYSTS.

THESE CHARTS SHOW THE BASELINE REPEATABILITY OF THE LOW WATTAGE CALORIMETER AND THE PRODUCTION CALORIMETER.

THE DATA HERE WAS COLLECTED OVER THE SAME THREE MONTH PERIOD FOR EACH CALORIMETER AND THERE WAS A SEASONAL SHIFT DURING THIS TIME - AND YOU CAN SEE AN IMPROVED BASELINE STABILITY WITH THE NEW CALORIMETER HAVING A .8 MW STANDARD DEVIATION AND THE OTHER CALORIMETER HERE HAVING A 3.5 MW STANDARD DEVIATION. 


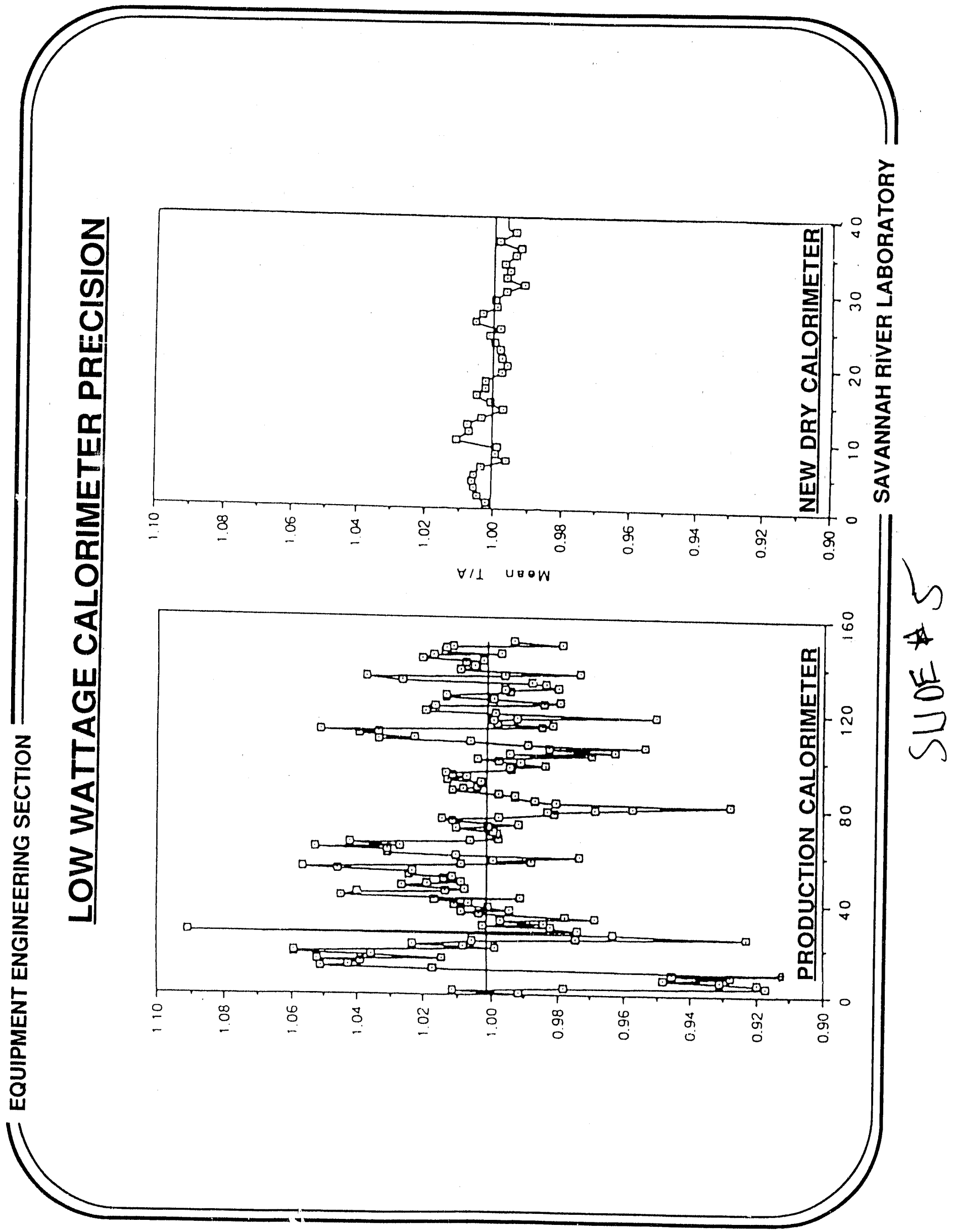




\section{SLIDE \#5 DISCUSSION}

THESE CHARTS HERE SHOW THE IMPROVED PRECISION OF THE NEW CALORIMETER.
A . IW RADIOMETRIC STANDARD WAS USED TO COLLECT THIS DATA.

THIS CHART SHOWS TIME FRAME HERE WHERE THE RECHECK RATE WAS AS HIGH AS 200\% AND WHEN THE NEW CALORIMETER WAS USED OVER HERE, THE RECHECK RATE WAS REDUCED TO ZERO. 


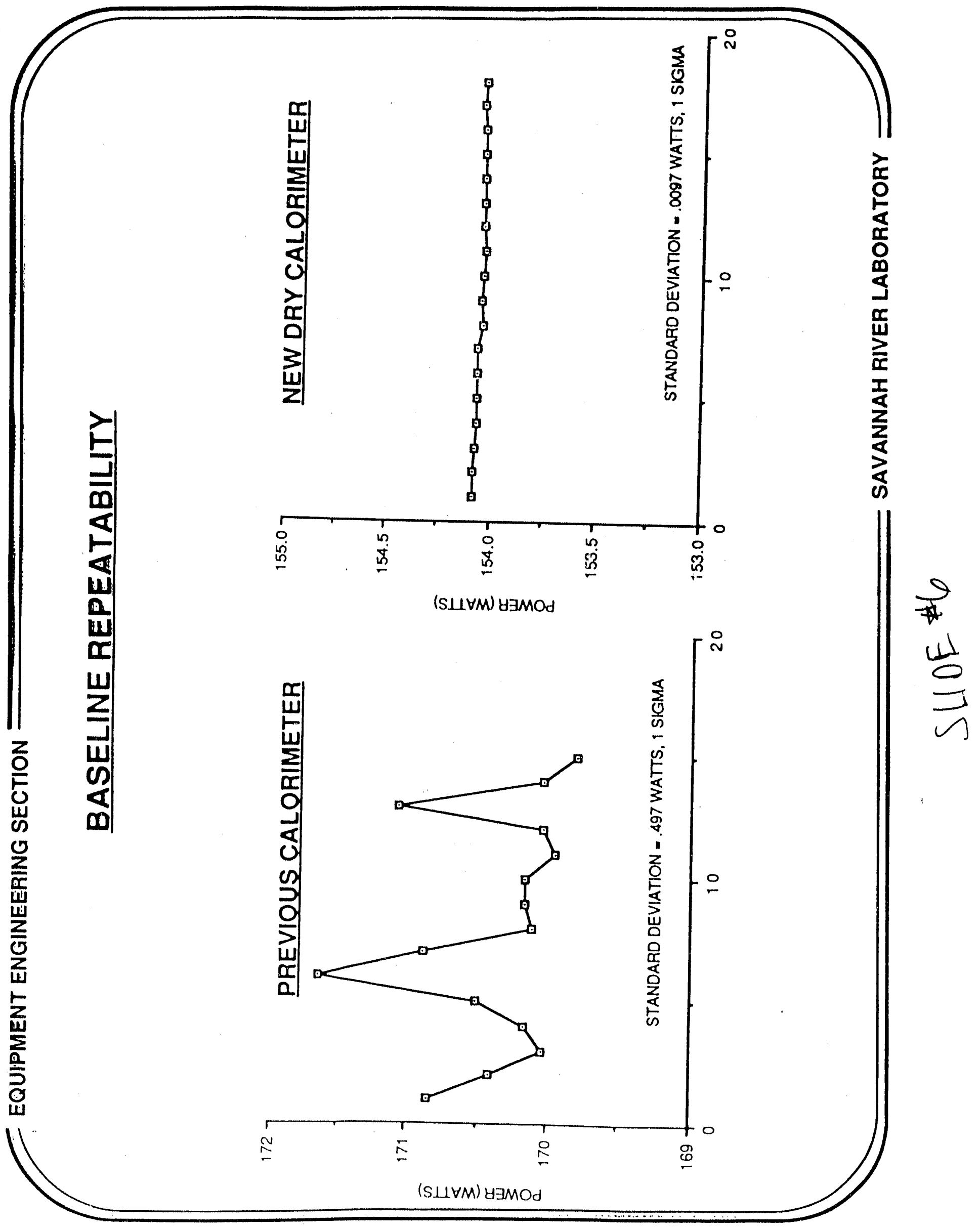


SLIDE \#6 DISCUSSION

HERE'S A COMPARISON BETWEEN THE PREVIOUS HIGH WATTAGE CALORIMETER AND OUR NEW CALORIMETER.

THIS CALORIMETER IS NO LONGER IN SERVICE; HOWEVER, I WAS ABLE TO COLLECT THESE BASELINE MEASUREMENTS FROM IT.

AND AS YOU CAN SEE THE BASELINE REPEATABILITY HAS BEEN IMPROVED DRAMATICALLY FROM ABOUT . 5 WATTS TO .01 WATTS ONE SIGMA. 


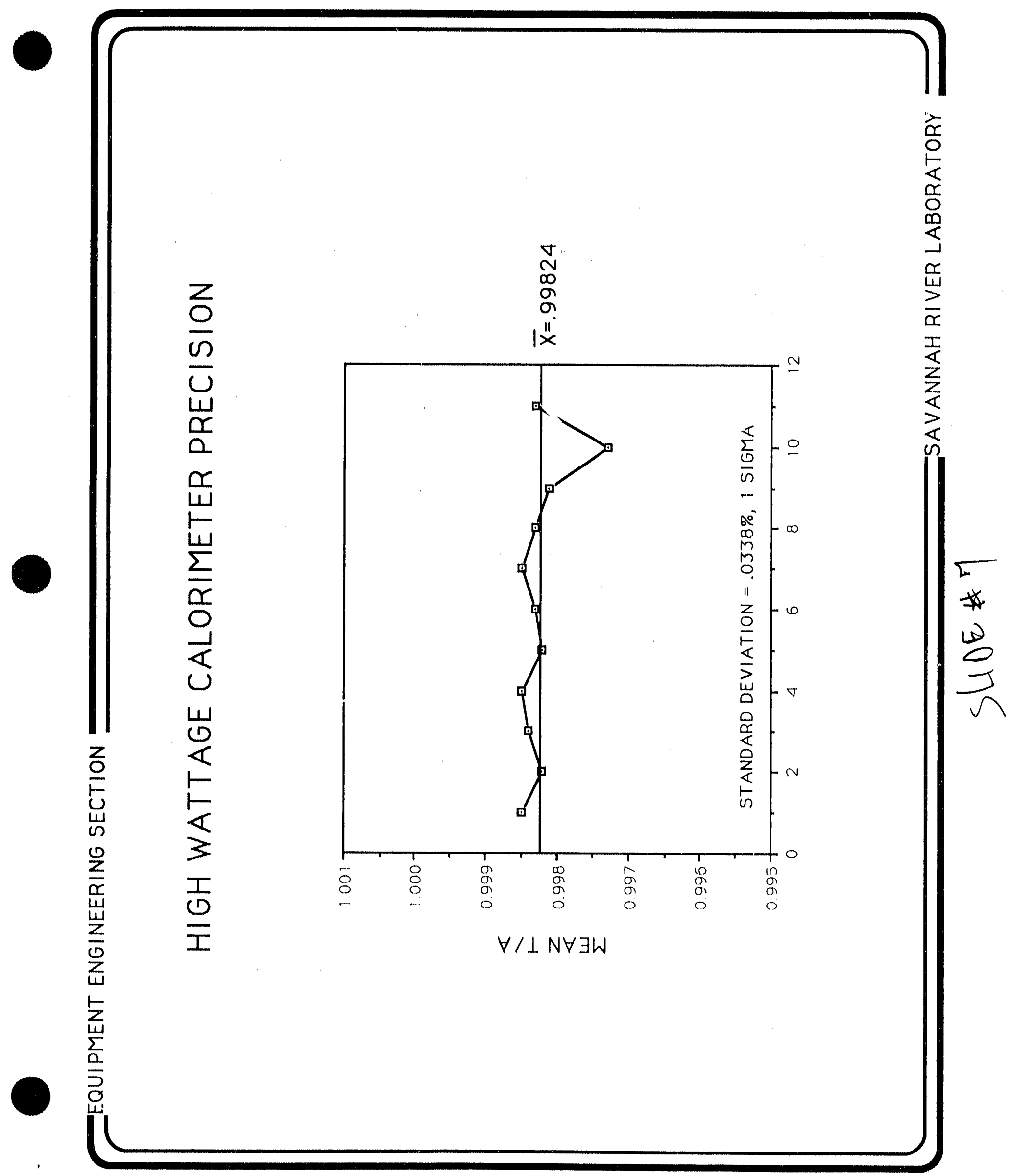


SLIDE \#7 DISCUSSION

THIS IS THE PRECISION OF THE NEW HIGH WATTAGE CALORIMETER.

A 140 WATT RADIOMETRIC STANDARD WAS USED TO COLLECT THIS DATA WHERE WE HAVE A . $2 \%$ BIAS WITH A .03\% STANDARD DEVIATION, 1 SIGMA.

THE PREVIOUS CALORIMETER HAD ABOUT A . 25\% STANDARD DEVIATION, 1 SIGMA. 


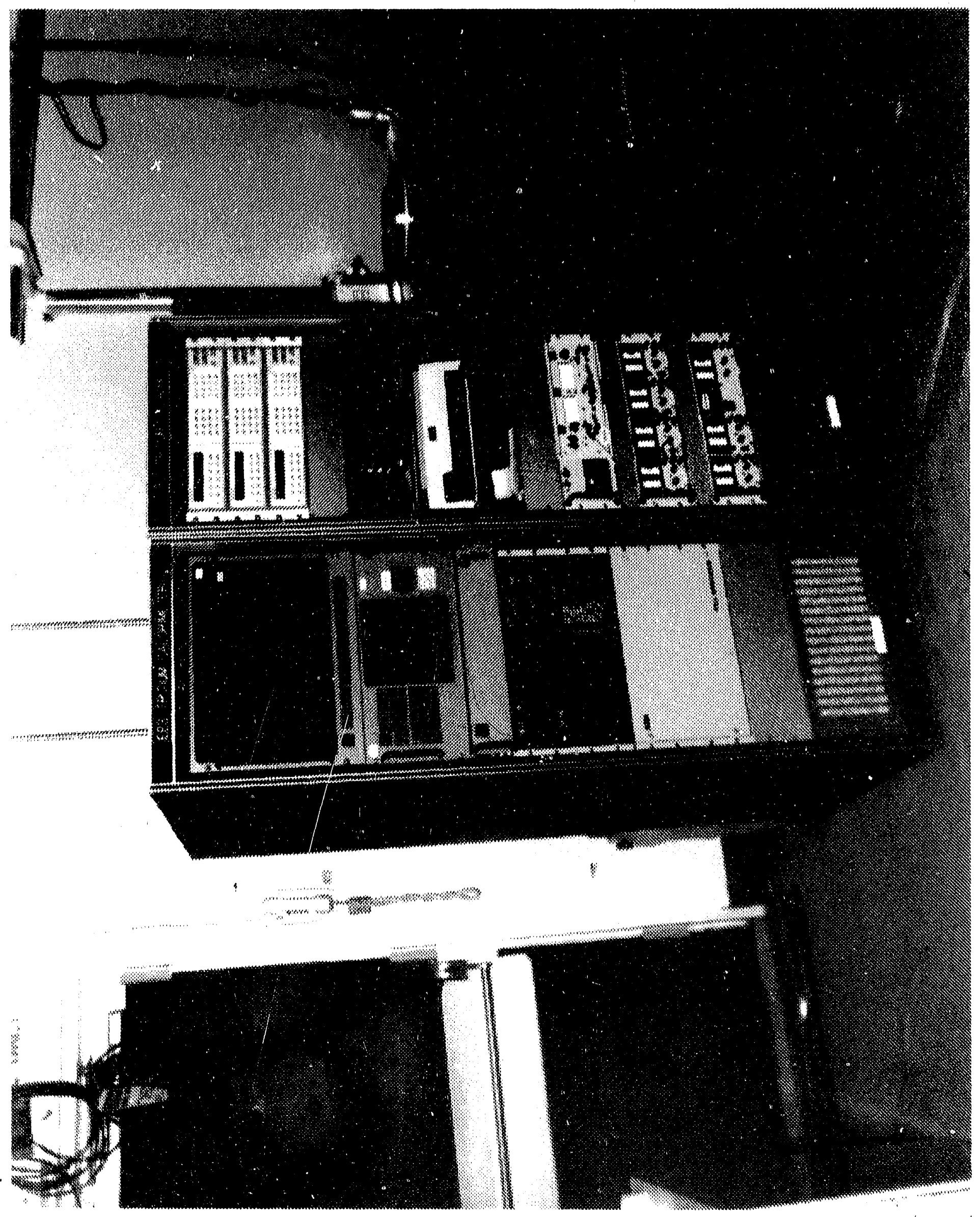


SLIDE \#8 DISCUSSION

NOW, I WOULD LIKE TO SHOW A COUPLE OF PICTURES OF OUR CALORIMETERS .

THIS FIRST ONE IS THE LOW WATTAGE CALORIMETER. WE HAVE TWO EQUIPMENT RACKS WITH A COMPUTER FOR CONTROL, VOLTMETERS, AND POWER SUPPLIES.

OVER HERE IS THE CALORIMETER BOX WHICH IS AN INSULATED

STAINLESS STEEL ENCLOSURE WHICH HOUSES THE CALORIMETER WELL. 


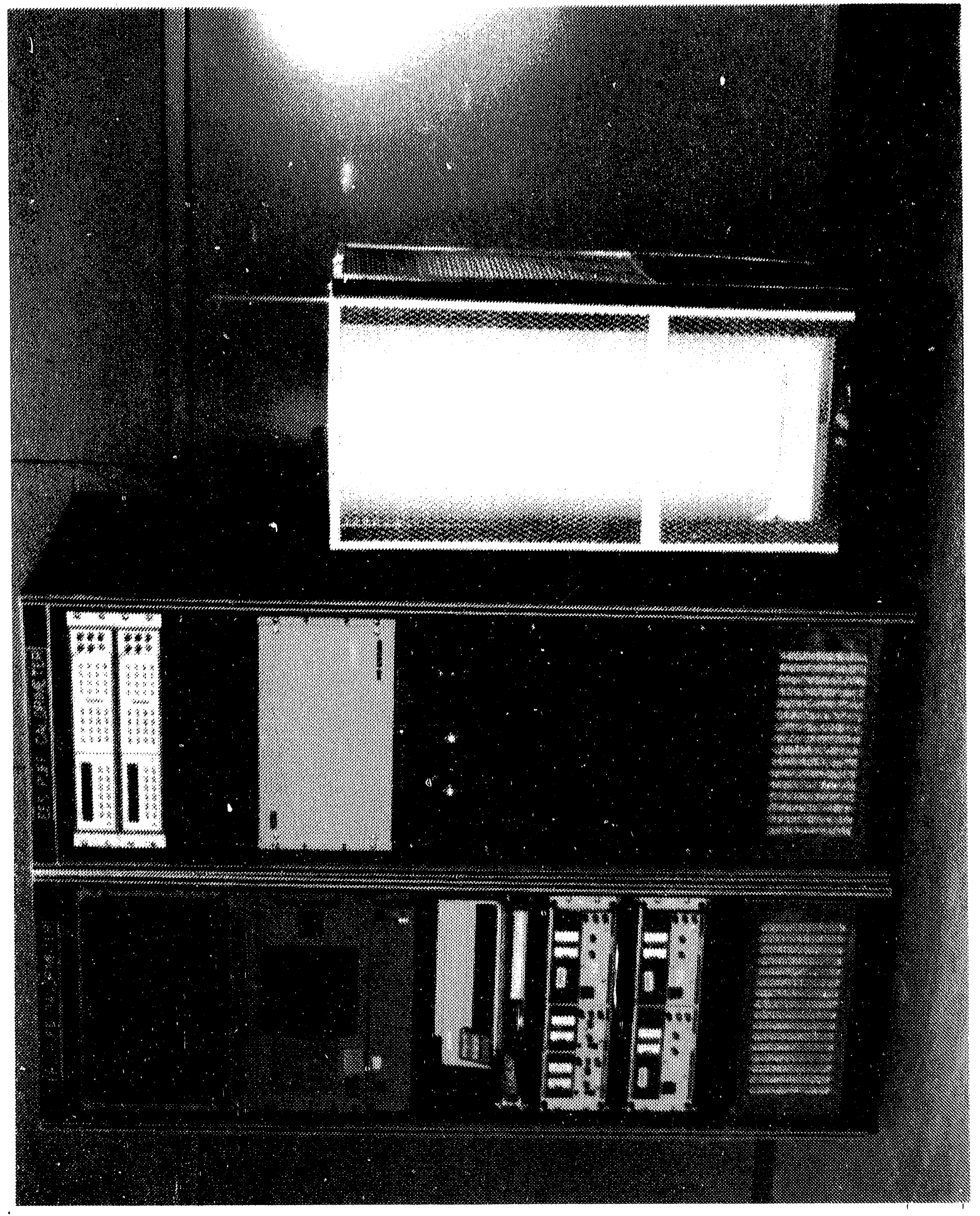


SLIDE \#9 DISCUSSION

THIS IS A PICTURE OF THE HIGH WATTAGE CALORIMETER WHERE WE HAVE TWO SIMILAR EQUIPMENT RACKS AND THIS IS THE CALORIMETER WELL SURROUNDED IN POLYINSUIATION. 
SLIDE \#10 DISCUSSION

GENERAL OPERATION

THESE CALORIMETERS BOTH USE POWER REPLACEMENT TECHNIQUES

WHERE THE CALORIMETER FIRST STABILIZES WITH A BASELINE ZERO POWER, SAY 1.5 WATTS.

AND THEN ONCE THE CALORIMETER HAS STABILIZED, THE OPERATOR WILI INSERT THE SAMPLE INTO THE WELL.

THE CALORIMETER WILL THEN STABILIZE WITH A NEW POWER, SAY 1 WATT, AND THE SAMPLE POWER IS THE SUBTRACTION OF BASELINE POWER MINUS THIS NEW POWER OR 1/2 WATT. 


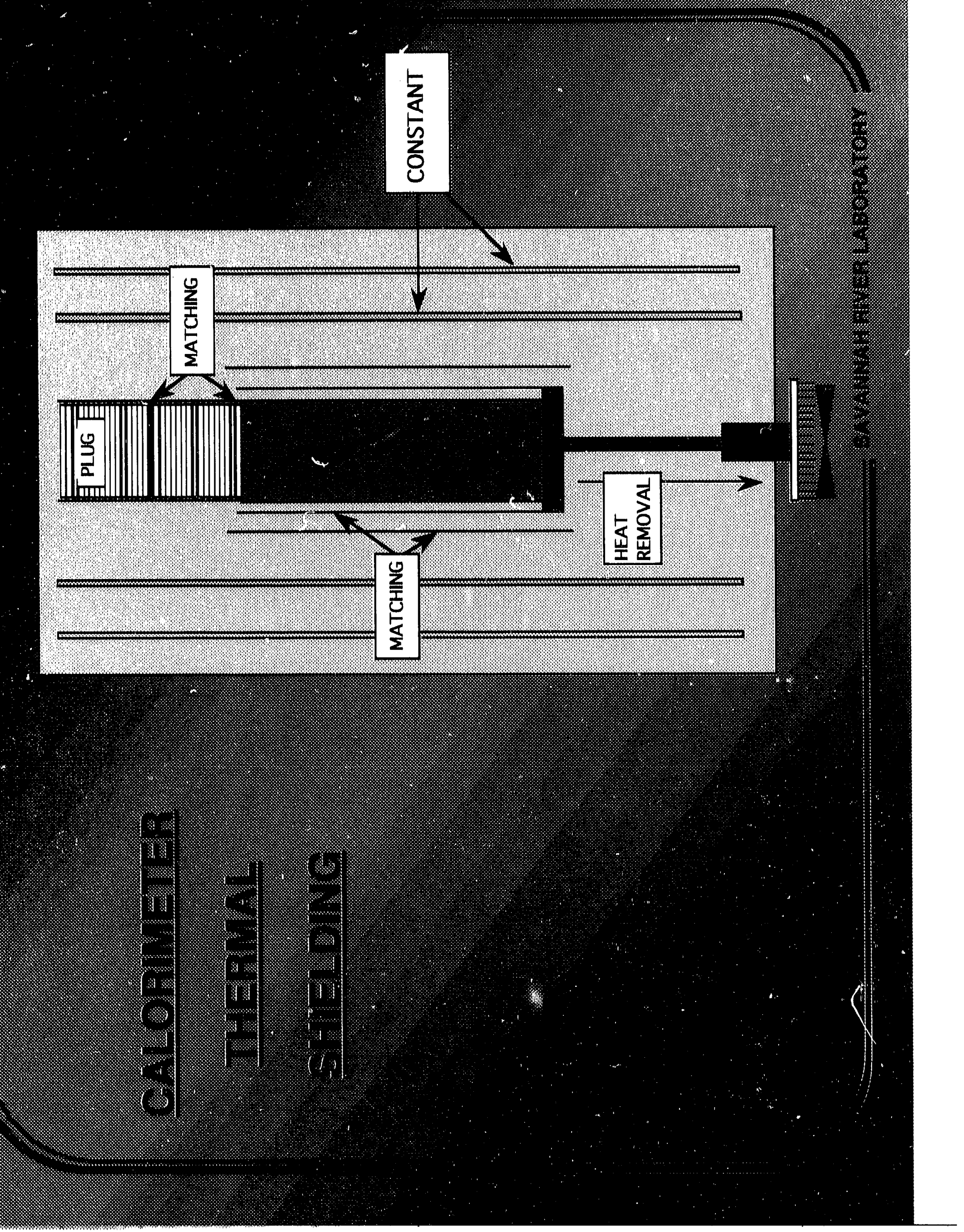


SLIDE \#11 DISCUSSION

HERE IS A PROFILE VIEW OF THE LOW WATTAGE CALORIMETER.

THIS IS THE PLUG WHICH IS REMOVED TO INSERT THE SAM THE WELL. THE PLUG IS MADE OF POLYFOAM INSULATION LAYERS OF ALUMINIZED MYLAR AND IS CONSTRUCTED TO RET Y, AIR EXCHANGE DUE TO PRESSURE DIFFERENTIALS.

THE WELL IS ABOUT 5" IN DIAMETER AND 12" DEEP AND IS MADE OF COPPER. THE OVERALL HEIGHT IS ABOUT 30" AND 10" IN DIAMETER.

THERE ARE THREE TYPES OF THERMAL CONTROL USED IN THIS CALORIMETER.

FIRST, THERE ARE TWO MATCHING TEMPERATURE SHIELDS TO ELIMINATE HEAT FLOW IN OR OUT OF THE WELL.

SECOND, THERE ARE TWO CONSTANT TEMPERATURE SHIELDS TO SHIELD THE CALORIMETER WELL FROM ROOM TEMPERATURE CHANGES.

THIRD, WE USE POLYFOAM WITH ALUMINIZED MYLAR WRAP FOR BOTH CONVECTIVE AND RADIANT INSULATION.

ADDITIONALLY, THE STAINLESS STEEL BOX WHICH SURROUNDS THIS CALORIMETER IS CONTROLLED TO A CONSTANT TEMPERATURE BY THERMOELECTRIC COOLING.

NOW, HEAT REMOVAL FROM THE WELL IS DOWN THIS COPPER ROD HERE . 


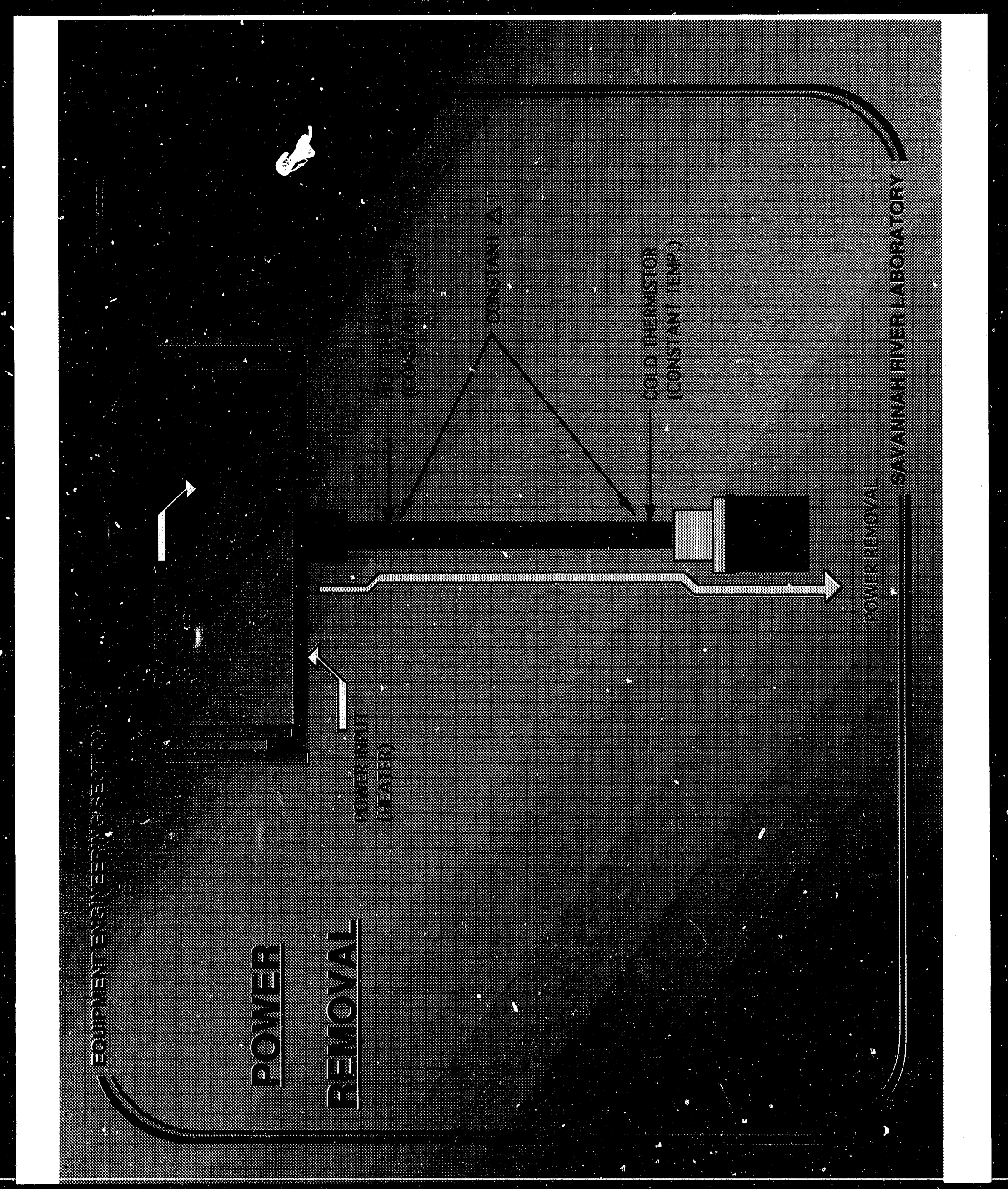




\section{SLIDE \#12 DISCUSSION}

AGAIN, THE CALORIMETER USES A POWER REPLACEMENT TECHNIQUE WHICH WE ACCOMPLISH BY INITIALLY SUPPLYING BASELINE POWER TO THE BASE OF THE WELL HERE.

THE AMOUNT OF THIS BASELINE POWER IS CONTROLLED TO KEEP THE TOP PART OF THIS HEAT REMOVAL ROD AT A CONSTANT TEMPERATURE.

THE LOWER PART OF THIS ROD IS KEPT AT A COOLER, CONSTANT TEMPERATURE BY THIS HEAT PUMP.

AND NOW WE HAVE CREATED A CONSTANT DELTA T DOWN THIS ROD OR A CONSTANT HEAT REMOVAL PATH FROM THE WELL.

NEXT, A SAMPLE IS PLACED IN THE WELL WHICH SUPPLIES ADDITIONAL THERMAL POWER.

WITH THIS ADDITIONAL THERMAL POWER PRESENT, THE AMOUNT OF POWER SUPPLIED BY THIS HEATER IS REDUCED BY THE SAMPLE POWER TO KEEP THE TOP OF THIS ROD AT A CONSTANT TEMPERATURE. 


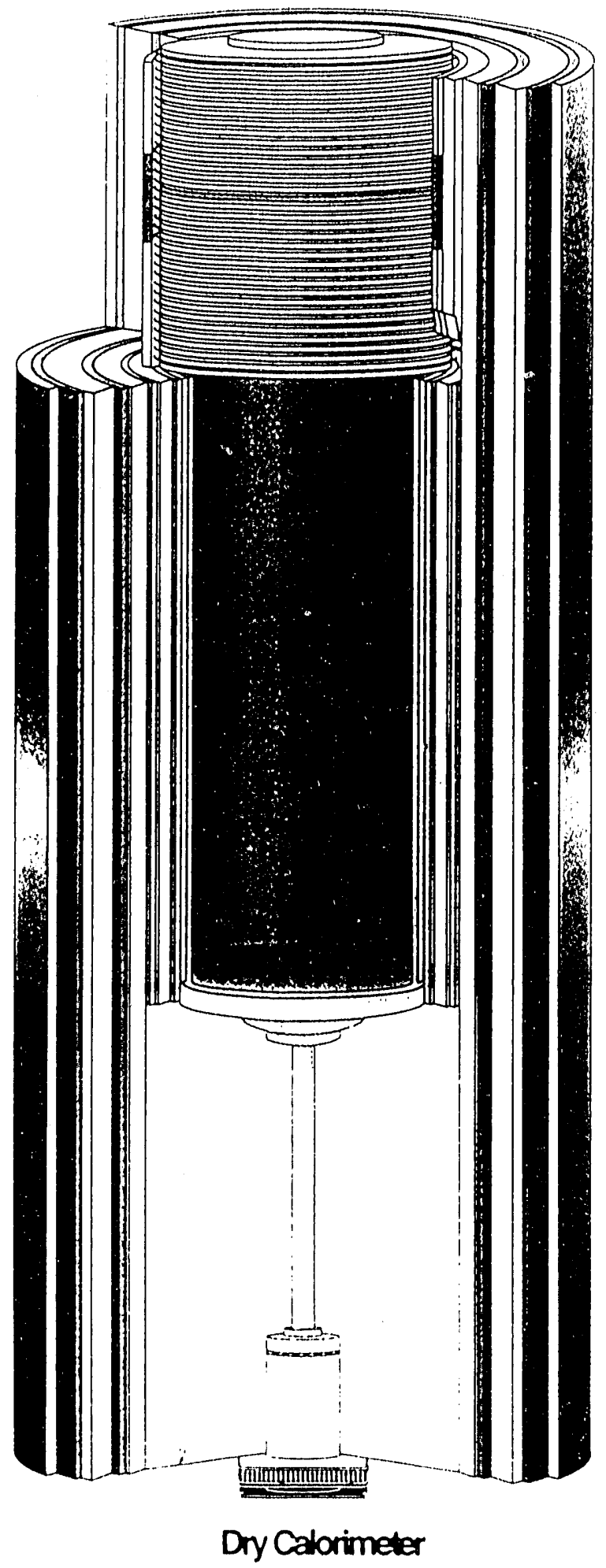

SLIDE \#/3 
SLIDE \#13 DISCUSSION

I WOULD LIKE TO SHOW YOU CUT AWAY VIEW OF THE LOW WATTAGE CALORIMETER HERE.

THIS IS THE PLUG SHOWING THE LAYERED CONSTRUCTION.

THE WELL IS THIS AREA HERE WITH THE HEAT REMOVAL ROD COMING DOWN TO THIS HEAT PUMP AND FINAL POWER REMOVAL IS THROUGH THIS SURFACE TO AIR THERMOELECTRIC COOLER.

AND YOU CAN SEE THE SHIELDS HERE AND LAYERS OF INSULATION. 


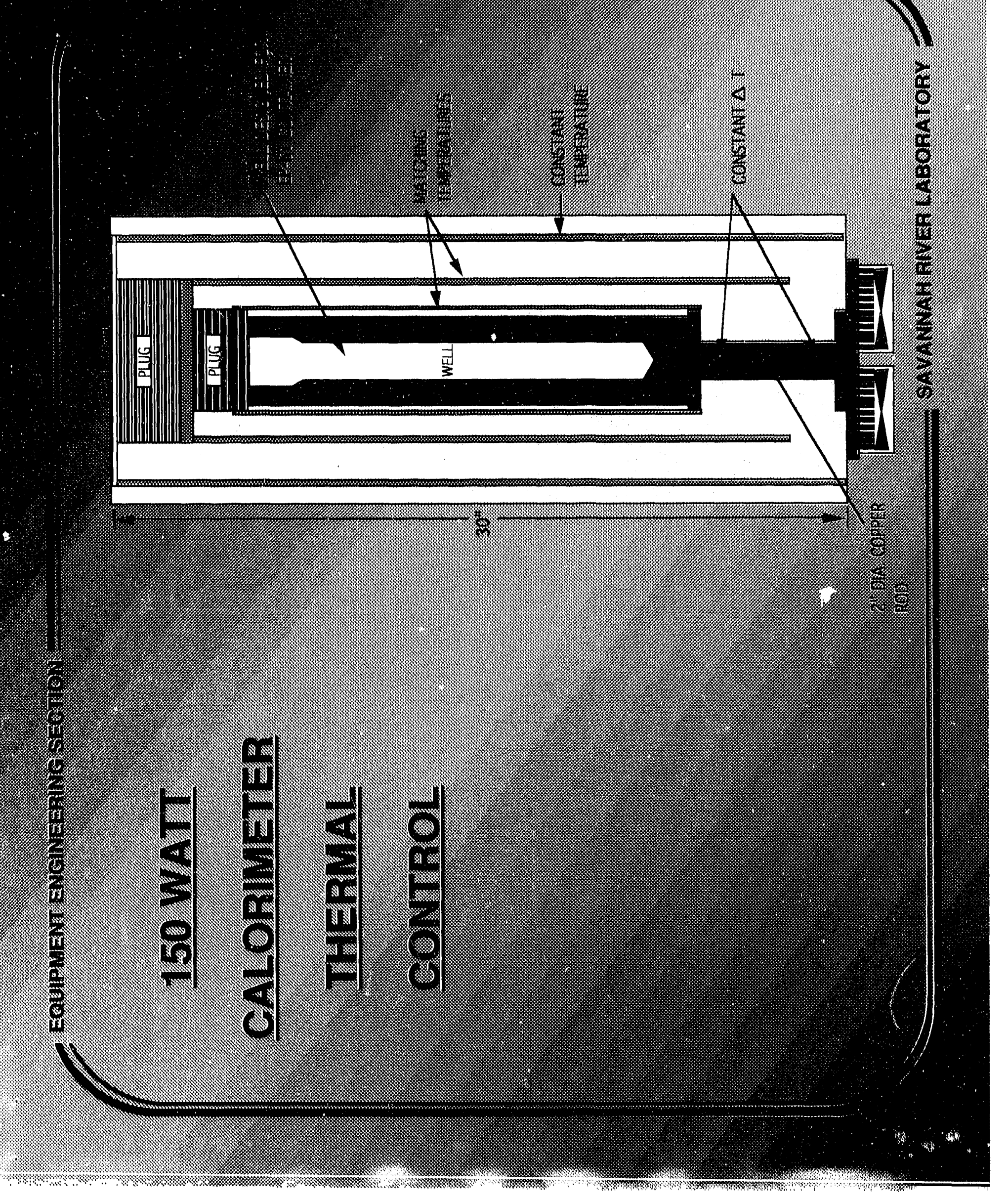


SLIDE \#14 DISCUSSION

BRIEFLY HERE I WOULD LIKE TO SHOW THE THERMAL SHIELDING FOR THE HIGH WATTAGE CALORIMETER.

IT USES THE SAME BASIC PRINCIPALS AS THE LOW WATTAGE CALORIMETER WITH THE EXCEPTION OF ONLY ONE MATCHING TEMPERATURE SHIELD AND ONE CONSTANT TEMPERATURE SHIELD.

ALSO, THE WELL IS SPECIFICALLY CONSTRUCTED TO HOLD ONE OF OUR SHIPPING CONTAINERS. 


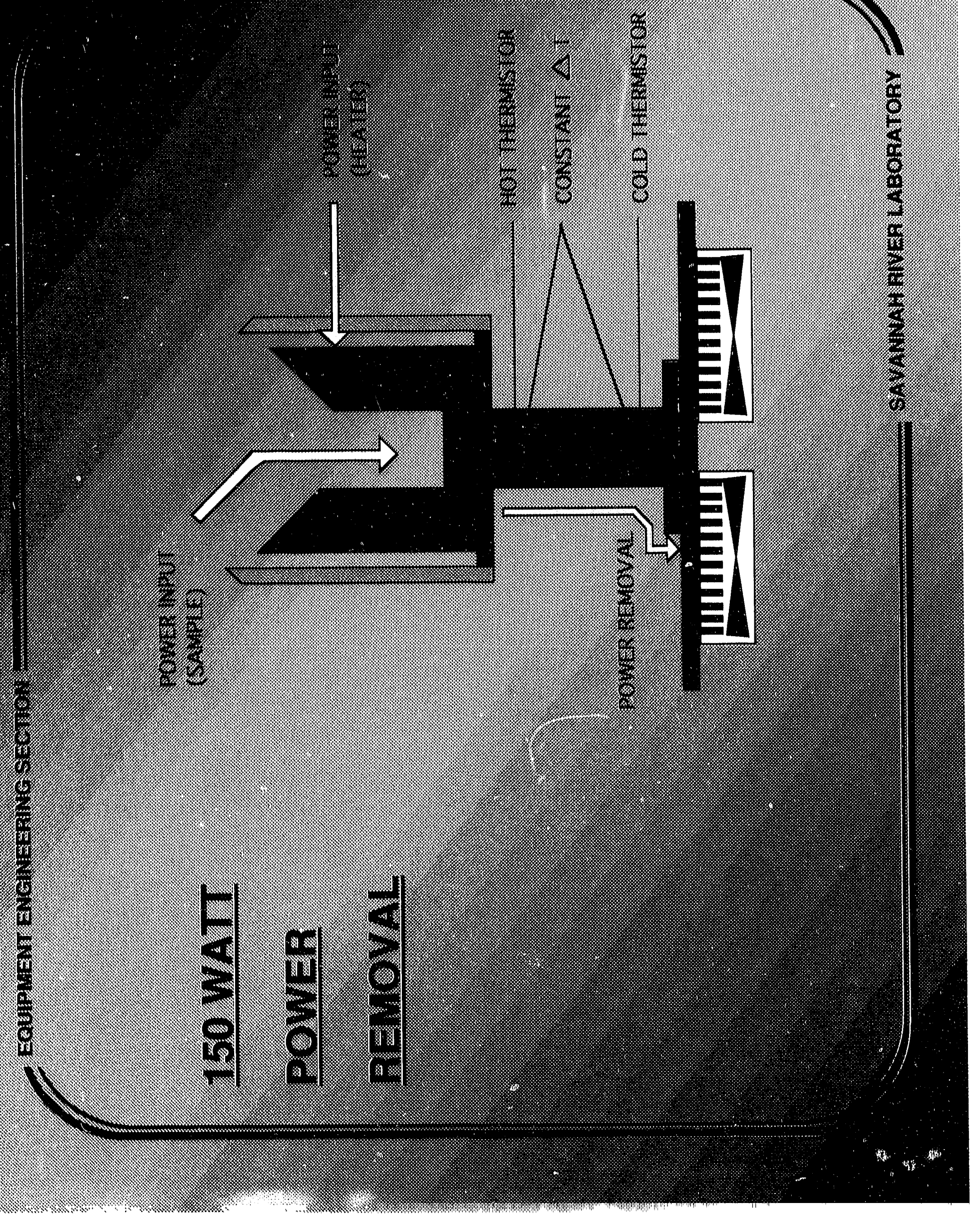




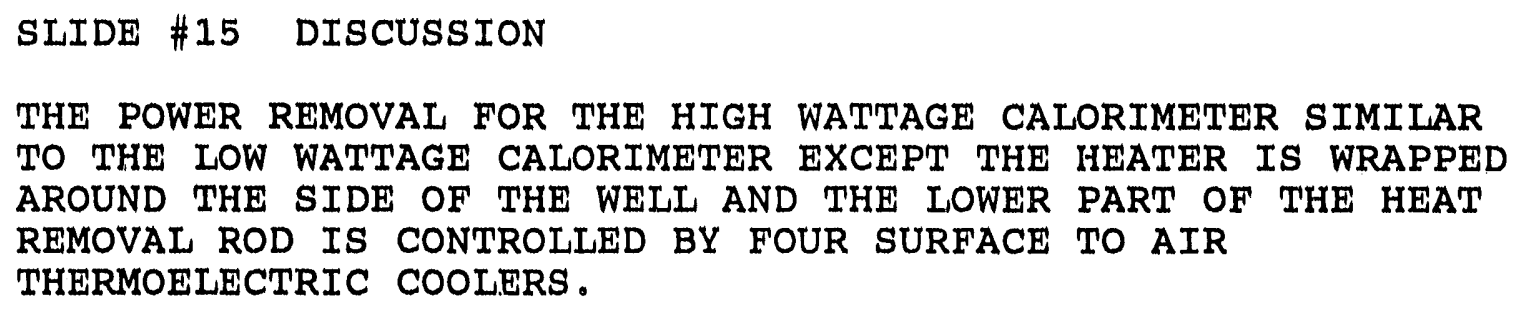



SLIDE \#16 DISCUSSION

TO CONTROL THE CALORIMETER WE USE HP-3457 DIGITAL

VOLTMETERS, AN IBM INDUSTRIAL COMPUTER AS THE SYSTEM CONTROLLER, BURR BROWN 16 BIT DIGITAL TO ANALOG CONVERTERS, AND KEPCO POWER SUPPLIES TO DRIVE THE HEATERS OR COOLERS.

THE CONTROL SYSTEMS FOR LOW AND HIGH WATTAGE CALORIMETERS OPERATE VERY MUCH THE SAME. 


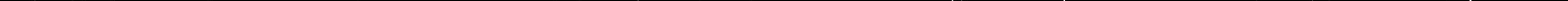




\section{SLIDE \#17 DISCUSSION}

HERE IS A TYPICAL CONTROL LOOP WHERE THE CYCLE IS INITIATED BY THE VOLTMETER MAKING A THERMISTOR MEASUREMENT WHICH IS REQUESTED BY THE COMPUTER VIA A 488 BUS.

THE THERMISTOR VALUES ARE PROCESSED THROUGH PROPORTIONALINTEGRAL-DERIVATIVE ALGORITHMS AND THE COMPUTER OUTPUTS A SMALL VOLTAGE THROUGH THE DIGITAL TO ANALOG CARDS.

THIS SMALL VOLTAGE IS AMPLIFIED BY THE KEPCO POWER SUPPLY WHICH DRIVES EITHER A HEATER OR COOLER.

THERMAL TRANSFER TAKES PLACE AND THE CYCLE IS REPEATED. 

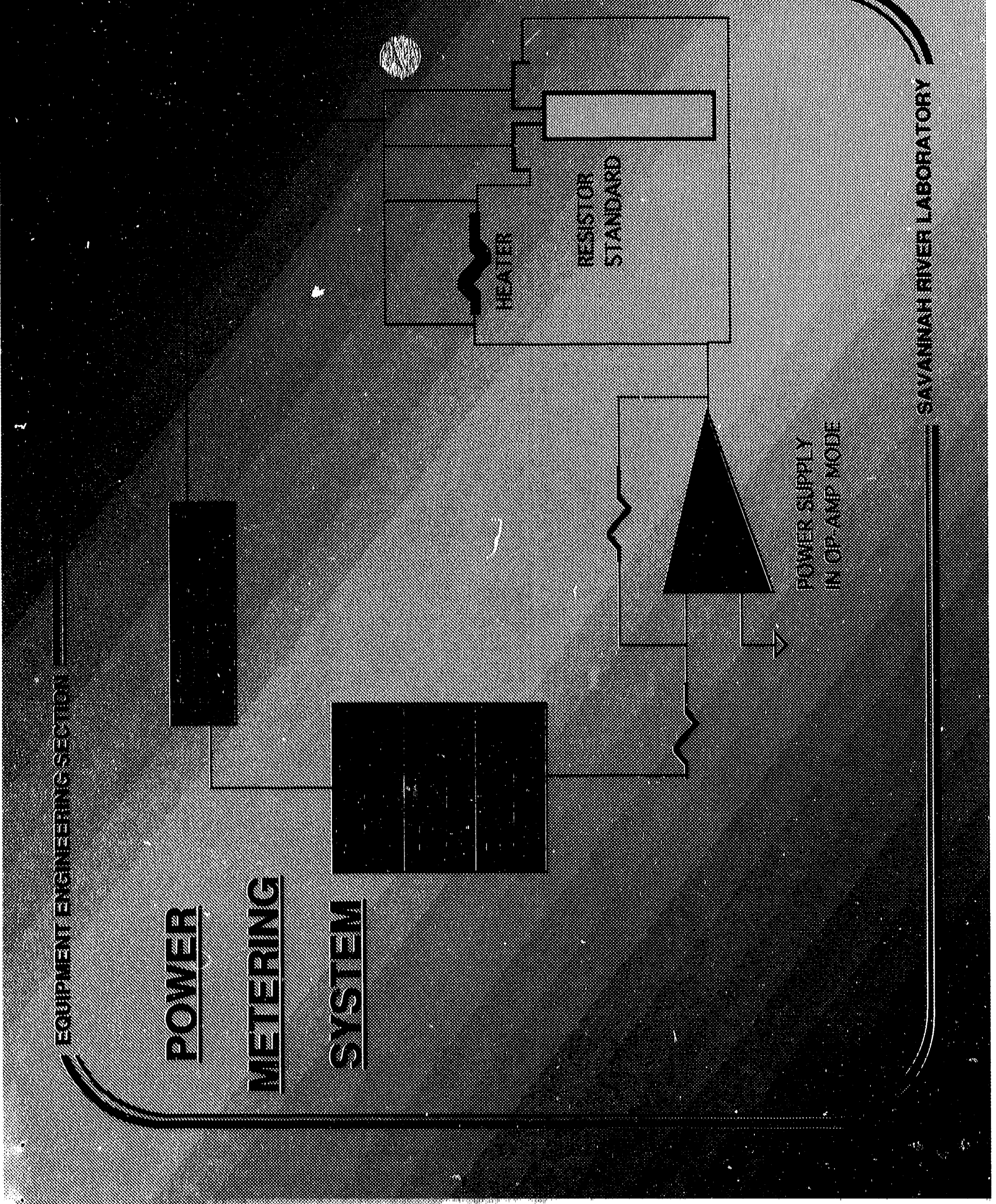
SLIDE \#18 DISCUSSION

THE POWER METERING SYSTEM IS A TYPICAL CONTROL LOOP EXCEPT THAT WE PLACE A STANDARD RESISTOR IN SERIES WITH THE HEATER POWER, AND THIS HEATER IS THE WELL HEATER.

VOLTAGES ARE MONITORED ACROSS THE STANDARD RESISTOR SO THAT WE CAN COMPUTE THE CURRENT AND THE VOLTAGE IS MEASURED ACROSS THE HEATER SO WE CAN MEAJURE THE POWER SUPPLIED TO THE WELL. 


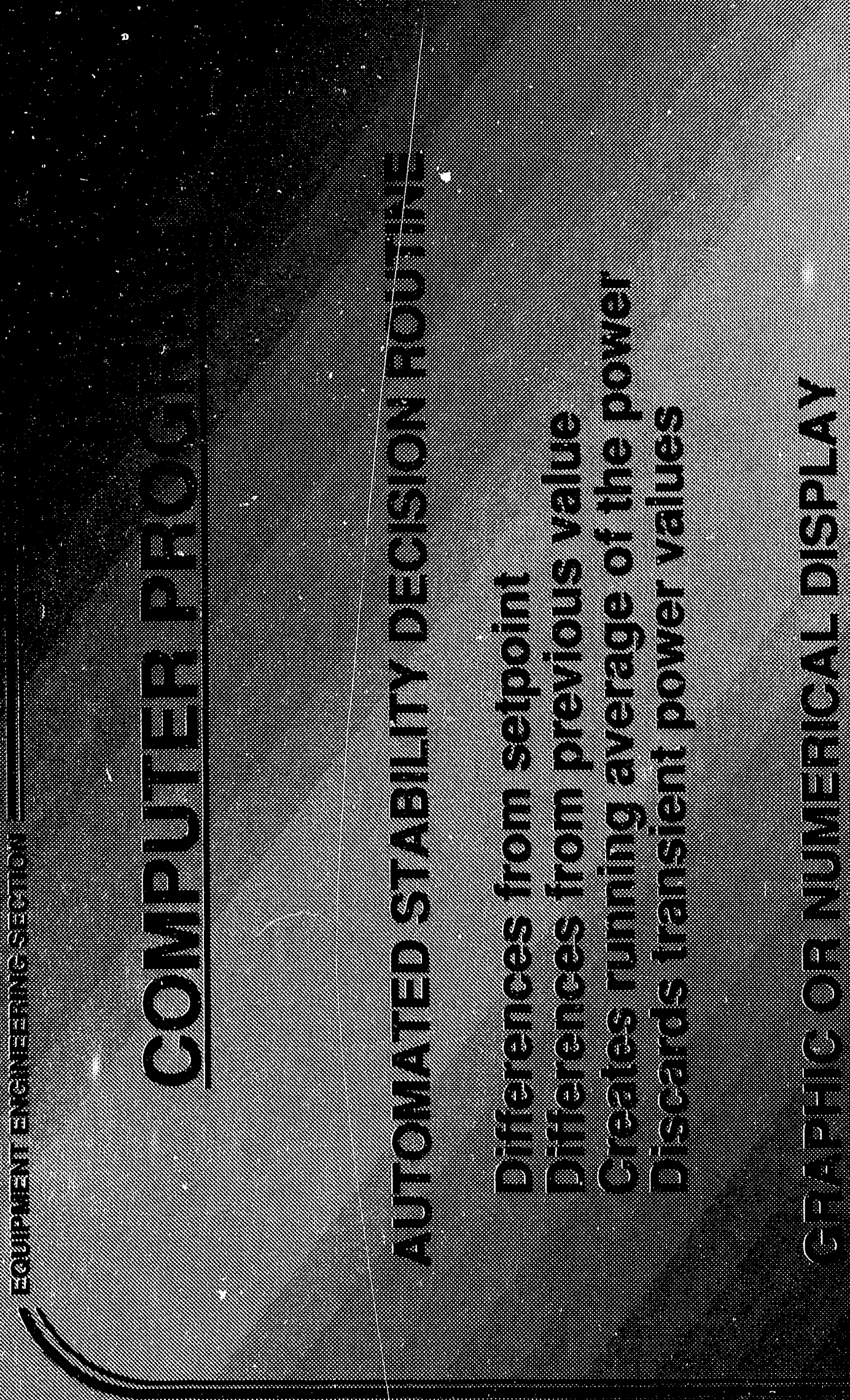




\section{SLIDE \#19 DISCUSSION}

I WOULD LIKE TO MENTION ONE HIGHLIGHT OF THE COMPUTER CONTROL PROGRAM.

IT HAS AN AUTOMATED STABILITY DECISION ROUTINE WHICH IS BASED ON DIFFERENCES FROM SETPOINT, SAY FOR THERMISTORS, AND DIFFERENCES FROM PREVIOUS VALUES WHICH IS APPLIED TO BOTH THERMISTOR READINGS AND POWER MEASUREMENTS.

THE PROGRAM WILL CREATE A RUNNING AVERAGE ONCE IT DECIDES IT IS STABLE. IT WILL CONTINUE THE AVERAGE FOR ABOUT A HOUR, AT WHICH TIME THE OPERATOR MAY READ THE POWER VALUE, OR UNTIL A TRANSIENT IS ENCOUNTERED.

THE POWER VALUES COLLECTED DURING THIS TRANSIENT PERIOD ARE NOT INCLUDED IN THE POWER AVERAGE. 


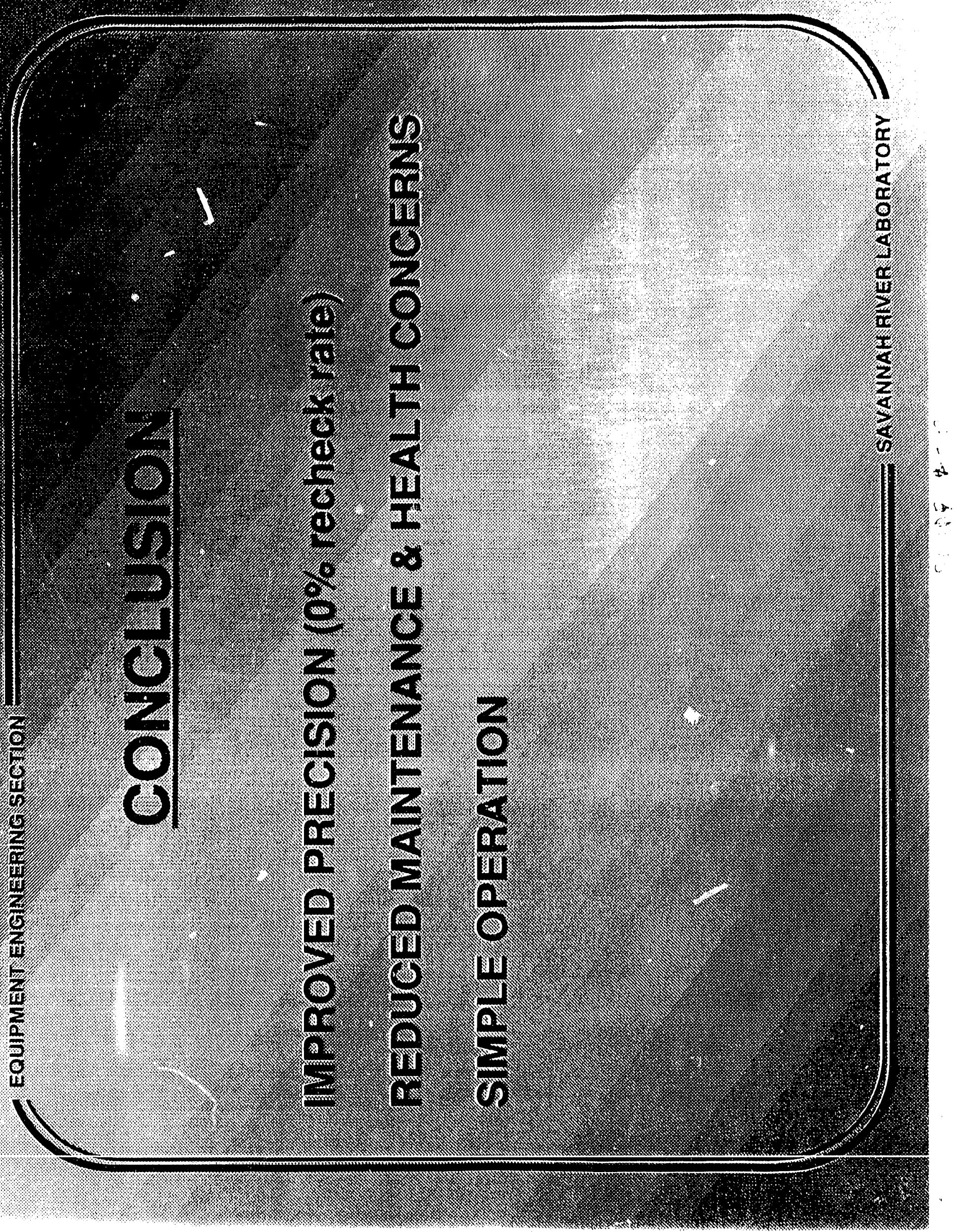


SLIDE \#20 DISCUSSION

AND IN CONCLUSION

WE HAVE IMPROVED PRECISION ESPECIALLY FOR LOW WATTAGE SAMPLES WHERE WE HAVE REDUCED THE RECHECK RATE TO ZERO. WE HAVE REDUCED BOTH MAINTENANCE AND HEALTH CONCERNS BY COMPLETE ELIMINATION OF WATER.

AND WE HAVE PROVIDED A SIMPLE TO OPERATE CALORIMETER. 

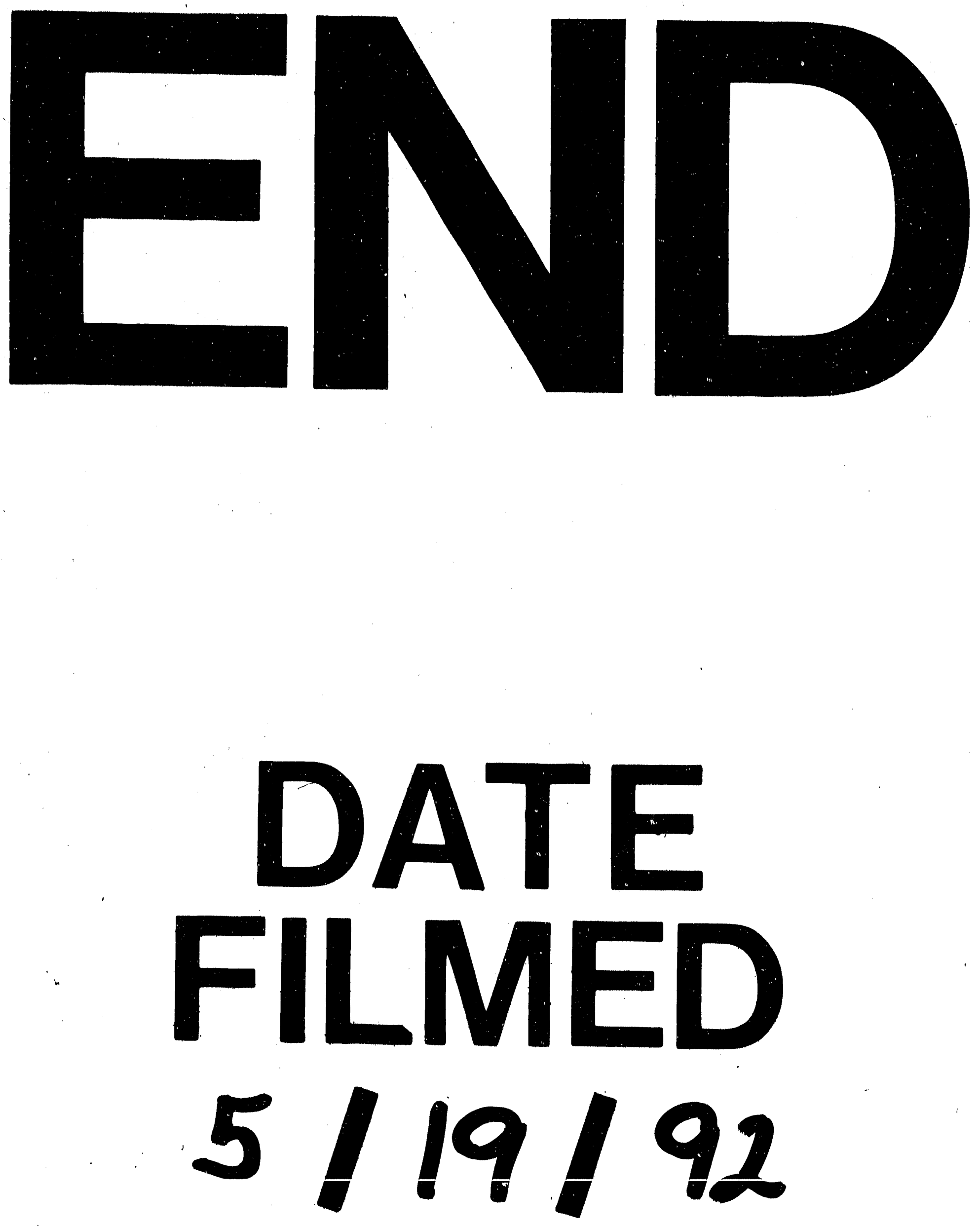
